\title{
Attenuation of Oxidative Stress and Hepatotoxicity Induced By D-Galactosamine by a Polyherbal Formulation Ambrex-in vivo and in vitro Studies
}

\author{
Anila Raslin1, Sekar Sathiya², Chidambaram Saravana Babu², Johanna Rajkumar ${ }^{1 *}$ \\ ${ }^{1}$ Department of Biotechnology, Rajalakshmi Engineering College,Thandalam, Chennai - 602105, Tamilnadu, INDIA. \\ ${ }^{2}$ Centre for Toxicology and Developmental Research, Sri Ramachandra University, Porur, Chennai - 600110, Tamilnadu, INDIA.
}

\begin{abstract}
Objective: To evaluate the hepatoprotective effect of Ambrex, a polyherbal formulation against D-galactosamine (D-GLN) induced hepatotoxicity in Swiss albino mice as well as in Chang liver cell lines. Materials and Methods: Ambrex was orally administered for a period of 7 days at dose levels of 250 and $500 \mathrm{mg} / \mathrm{kg} \mathrm{b.wt.} \mathrm{D-GLN}(250 \mathrm{mg} / \mathrm{kg} \mathrm{b} . w \mathrm{w}$, i.p) was administered $24 \mathrm{~h}$ prior to sacrifice the animals. The protective effect of Ambrex was evaluated by measuring plasma levels of aspartate transaminase (SGOT), alanine transaminase (SGPT), alkaline phosphatase (ALP), $\gamma$-glutamyltransferase ( $\gamma \mathrm{GT}$ ) and total bilirubin. Its effect on antioxidants such as superoxide dismutase (SOD), catalase (CAT) and reduced glutathione (GSH) and lipid peroxide(LPO) was also determined. Histopathological evaluation of liver tissues was carried out. Results: Data revealed that Ambrex was able to restore the levels of antioxidants such as SOD, Catalase, and Glutathione to near normal and reduced the elevated plasma levels of SGOT, SGPT, ALP, $\gamma-$ GT and total bilirubin. It also inhibited the formation of hepatic malondialdehyde induced by D - GLN. In vitro studies revealed that Ambrex protected D- GLN induced hepatotoxicity $(30 \mu \mathrm{M} /$ $\mathrm{ml}$ ) at dose levels of 5,50 and $500 \mathrm{ng} / \mathrm{ml}$. Further, mRNA expression also illustrated that Ambrex inhibited the over expression of Bax, Caspase 3, TNF- $\alpha, \mathrm{IL}-2$ and CYP-450. A substantial decrease in the mRNA expression of anti-apoptotic marker $\mathrm{Bcl} 2$ was also observed. Conclusion: Results suggest that Ambrex has appreciable hepatoprotective effect which was evident from both in vivo and in vitro results.
\end{abstract}

Key words: Ambrex, D- Galactosamine, Hepatotoxicity, Chang Cells, Antioxidants.

\section{INTRODUCTION}

D-GLN, a hepatotoxin and transcription inhibitor sensitizes hepatocytes to the cytotoxication via series of mechanisms. Diminution of uridine triphosphate (UTP) nucleotides with formation of uridine diphosphate (UDP) hexosamines and loss of intracellular calcium levels are the associated mechanisms following induction of D-GLN, ultimately leading to inhibition of RNA and DNA syntheses. ${ }^{1-2}$ Further, inhibition of hepatocyte energy metabolism, with impairment of liver marker enzymes and alteration in the membrane phospholipid composition were also reported characteristics of D-GLN induced liver damage. ${ }^{3}$ Javle and his workers ${ }^{4}$ reported that D-GLN induced liver injury is associated with the development of renal failure. D-GLN also causes an elevation of $\mathrm{TNF} \alpha$ with increased formation of reactive oxygen species (ROS) which might be circuitously a reason for cellular oxidative insult, thereby altering the antioxidant status. ${ }^{5}$

Regardless of substantial advancement in the treatment of liver disease with modern drugs, search for trail blazing drugs continues because of the side effects and limitations in the prolonged usage of existing conventional therapies. ${ }^{6}$ Medicinal plants
Submission Date: 23-07-2015; Revision Date: 29-09-2015; Accepted Date: 13-02-2016

DOI: 10.5530/ijper.51.4.107 Correspondence: Dr.Johanna Rajkumar, Professor and Head Department of Biotechnology, Rajalakshmi Engineering College, Rajalakshmi Nagar Thandalam, Chennai602105, Tamilnadu, INDIA. Phone no: 044 23860464; E-mail: anilaaphd@gmail. com

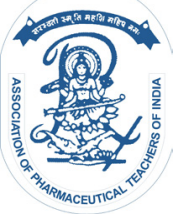

www.ijper.org 
and herbal formulations derived from natural sources have antioxidant or free radical scavenging activity has turn out to be a central focus for research designed to prevent toxicity or tissue injury and may have a significant role in maintaining health. ${ }^{7}$ Ambrex, a polyherbal formulation constitutes five medicinal plants namely Withaniasomnifera $(100 \mathrm{mg}$, amber $(37.50 \mathrm{mg})$, Pistacia lentiscus (25mg), Orchismascula (25mg) and Cycascircinalis $(62.5 \mathrm{mg})$. The medicinal plants present in this formulation possess broad medicinal values individually and was mentioned under Ayurvedic text. The formulation was already reported for its potential protection against butylated hydroxyl toluene (BHT) induced toxicity, ${ }^{8}$ gastro protective property ${ }^{9}$ and antihyperlipidemic property. ${ }^{10}$ The present study was designed to evaluate the hepatoprotective effect of Ambrex in in vivo and in vitro models.

\section{MATERIALS AND METHODS}

\section{Drugs and Chemicals}

All cell culture solutions and supplements were purchased from Life Technologies Inc., USA. Dulbecco's Modified Eagle Medium (DMEM) was obtained from GIBCO, USA. D-GLN was obtained from Himedia, India. LIV-52 was purchased from Himalayas, India. Biochemical kits were obtained from Merck, India. Ambrex was procured from Care and Cure Herbs Ltd., India. All other chemicals and reagents were of analytical grade obtained from Himedia, India and Sisco Research Laboratories Pvt. Ltd., India.

\section{Standardisation of Ambrex for curcumin content}

Since Ambrex is a polyherbal formulation containing five medicinal plants, we planned to standardise it using a chemical marker which possesses wider biological activity. Curcumin was known for its anti- tumor, oxidant, arthritic, amyloid, ischemic and inflammatory properties. Curcumin was found to be the ideal candidate to satisfy the above criterion. Ambrex was standardised for curcumin content by HPTLC method. ${ }^{11}$

\section{In vivo Study}

\section{Animal Husbandry}

Young healthy male swiss albino mice (18-22 g) were obtained from central animal facility, Sri Ramachandra University, Chennai, India. Animals were housed in colony cages (6 animals/cage) and were kept under laboratory standard conditions with $22 \pm 3^{\circ} \mathrm{C}$ temperature, 12-h light/12-h dark cycle and 30-70\% relative humid- ity. They were provided with rodent feed (M/s. Provimi Animal Nutrition India Pvt. Ltd, India) and purified water ad libitum. Animals were acclimatized at least for 7 days to the laboratory conditions prior to initiation of the experiment. Guidelines of "Guide for the Care and Use of Laboratory Animals" (Institute of Laboratory Animal Resources, National Academic Press 1996; $\mathrm{NIH}$ publication number \#85-23, revised 1996) were strictly followed throughout the study. Institutional Animal Ethical Committee (IAEC), Sri Ramachandra University, Chennai, India approved the study (IAEC No: IAEC/XXXIII/SRU/268/2013).

\section{Experimental Study Design}

The experimental animals were divided into five groups with six animals in each. Group I served as normal control - received vehicle. Group II received single dose of D-GLN (250 mg $/ \mathrm{kg}$ i.p.). Group III served as reference control received LIV-52 (100 mg/kg p.o.) + D-GLN $(250 \mathrm{mg} / \mathrm{kg}$ i.p). Group IV \& V received Ambrex at 250 and $500 \mathrm{mg} / \mathrm{kg}$ p.o. + D-GLN (250 mg/kg i.p.). Animals were pre-treated with vehicle or respective drug for a period of 7 days. D-GLN was injected on day 7, blood were collected $24 \mathrm{~h}$ following D-GLN injection from the over-night fasted mice through retro orbital puncture and sacrificed. Liver tissue was excised out, cleared of blood in ice cold saline and stored in $-80^{\circ} \mathrm{C}$.

\section{Biochemical Assays}

\section{Plasma biochemical parameters}

SGOT, SGPT, ALP, $\gamma$-GT and total bilirubin were measured using commercial diagnostic kits (Accurex, India) in semi-automatic biochemical analyser (Biosystem, India)

\section{SOD Activity}

SOD activity was performed by taking $0.05 \mathrm{ml}$ of $10 \%$ tissue homogenated followed by addition of $0.3 \mathrm{ml}$ of sodium pyrophosphate buffer (0.025 M, pH 8.3), 0.025 $\mathrm{ml}$ of phenasonium methosulphate $(186 \mu \mathrm{M})$ and 0.075 $\mathrm{ml}$ of nitroblue tetrazolium $(300 \mu \mathrm{M}$ in buffer of $\mathrm{pH}$ 8.3) The reaction was started by addition of $0.075 \mathrm{ml}$ of NADH $(780 \mu \mathrm{M}$ in buffer of $\mathrm{pH}$ 8.3). After incubation at $30^{\circ} \mathrm{C}$ for 90 seconds, the reaction was stopped by addition of $0.25 \mathrm{ml}$ glacial acetic acid. Then the reaction mixture was stirred vigorously and shaken with $2.0 \mathrm{ml}$ of $\mathrm{n}$-Butanol. The mixture was allowed to stand for 10 minutes and centrifuged. $1.5 \mathrm{ml}$ of $\mathrm{n}$-butanol alone was served as blank. The colour intensity of the chromogen was read at $560 \mathrm{~nm}$ using Thermo Scientific multi-scan spectrophotometer, USA. ${ }^{12}$ 


\section{LPO content}

The method involved heating of $0.2 \mathrm{ml}$ of $10 \%$ tissue homogenate with $0.8 \mathrm{ml}$ saline, $0.5 \mathrm{ml}$ of butylated hydroxyl toluene and $3.5 \mathrm{ml}$ thiobarburic acid (TBA) reagent for $1 \frac{1}{2} \mathrm{~h}$ in a boiling water bath. After cooling, the solution was centrifuged at $3500 \mathrm{rpm}$ for $10 \mathrm{~min}$ and the precipitate obtained was removed. The absorbance of the supernatant was determined at $532 \mathrm{~nm}$ using spectrophotometer (Thermo Scientific multi-skan spectrophotometer, USA) against a blank that contained all the reagents except the sample. ${ }^{13}$

\section{GSH content}

Glutathione content was estimated according to the method of Moren et al..$^{14} 0.25 \mathrm{ml}$ of $10 \%$ homogenate was added to equal volume of ice cold $5 \%$ trichloro acetic acid. The precipitate was removed by centrifugation at $3500 \mathrm{rpm}$ for 10 minutes. To $1 \mathrm{ml}$ of the supernatant, $0.25 \mathrm{ml}$ of $0.2 \mathrm{M}$ phosphate buffer, $\mathrm{pH} 8.0$ and $0.5 \mathrm{ml}$ of DTNB (0.6 mM in $0.2 \mathrm{M}$ phosphate buffer, $\mathrm{pH} 8.0$ ) was added and mixed well. The absorbance was read at $412 \mathrm{~nm}$ using Thermo Scientific multi-skan spectrophotometer, USA.

\section{CAT activity}

Catalase assay was performed as described by Sinha. ${ }^{15}$ The reaction mixture contained $\mathrm{H}_{2} \mathrm{O}_{2}(2 \mathrm{mM}), 0.2 \mathrm{ml}$ of the homogenate in a final volume of $1 \mathrm{ml}$ in phosphate buffer $(10 \mathrm{mM}, \mathrm{pH} 7.4)$. It was incubated at $37^{\circ} \mathrm{C}$ for $5 \mathrm{~min}$ and then Dichromate Acetic Acid reagent (5\% Potassium dichromate in water, Glacial Acetic Acid mixed in 1:3 ratio) was added and absorbance was taken at $570 \mathrm{~nm}$ using Thermo Scientific multi-skan spectrophotometer, USA. $2 \mathrm{ml}$ Dichromate Acetic acid reagent acts as blank whereas the reaction mixture without homogenate acts as control.

\section{Histopathology}

The experimental animals were sacrificed using anesthetic ether, liver was excised out and fixed in 10\% neutral buffered formalin solution for 48 hours. The tissue was then trimmed, dehydrated in graded alcohol and embedded in paraffin. Paraffin sections of 3-4 micron thickness were obtained, mounted on glass slides, counter-stained with Haematoxylin and Eosin (H\&E) and examined under light microscopy.

\section{In vitro Study}

\section{Cell Proliferation Assay or MTT Assay}

Cell respiration as an indicator of cell viability and proliferation was determined using a mitochondrial dependent reduction of 3-(4, 5-dimethylthiazol-2-yl)-2,
5- Diphenyl tetrazolium bromide (MTT) to formazan. Pre-confluent Chang liver cells were seeded in 96-well plates at a density of $8,000 \mathrm{cell} / \mathrm{s} / 200 \mu \mathrm{l} /$ well. Cells were treated with different concentrations of $\mathrm{D}$-galactosamine hydrochloride $(1,3,10,30,100,300$ and 1000 $\mu \mathrm{M})$ after $24 \mathrm{~h}$ following plating and incubated at $37^{\circ} \mathrm{C}$ for one day. At $20 \mathrm{~h}$ following drug exposure, the cells were incubated at $37^{\circ} \mathrm{C}$ with $0.5 \mathrm{mg} / \mathrm{ml}$ MTT for $4 \mathrm{~h}$. At the end of the experiment, the medium was removed, and the insoluble formazan product was dissolved in DMSO $(200 \mu \mathrm{l})$ and kept at least 15 minutes in dark. The intensity of purple blue colour developed was measured at 570 and $630 \mathrm{~nm}$ using Thermo scientific multi-scan spectrophotometer, USA. Percentage growth inhibitory rate of the test drug was calculated using the formula $\%$ Growth inhibitory rate $=([$ Control OD - Test OD $]$ / Control OD) *100

\section{D-GLN induced hepatotoxicity in Chang liver cells}

Chang liver cells were seeded in 6 well plates at a density of $1 \times 10^{5}$ cells/well and allowed to grow for a period of $24 \mathrm{~h}$. Ambrex was administered at a concentration of 5, 50 and $500 \mathrm{ng} / \mathrm{ml}$. One hour following test drug exposure, D-GLN $(30 \mu \mathrm{M} / \mathrm{ml})$ was added to each well except the control and incubated for a period of $24 \mathrm{~h}$. Cells were then trypsinised for measuring gene expressions of BAX, BCL-2, Caspase 3, TNF- $\alpha$, IL-2 and CYP-450.

\section{Reverse transcriptase - Polymerase Chain Reaction (RT-PCR)}

Total RNA was extracted using TRIzol Reagent (Sigma, USA). ${ }^{16}$ After homogenizing the cells with TRIzol reagent, the tubes was incubated for $10 \mathrm{~min}$ and centrifuged at $1000 \mathrm{rpm}$ for $5 \mathrm{~min} .200 \mu \mathrm{l}$ of chloroform was added to the supernatant, allowed to incubate for $5 \mathrm{~min}$ at room temperature and centrifuged at $12000 \mathrm{rcf}$ for $20 \mathrm{~min}$. Then $500 \mu \mathrm{l}$ of isopropyl alcohol was added to the supernatant to precipitate the total RNA and centrifuged at $12000 \mathrm{rcf}$ for $15 \mathrm{~min}$ following the incubation period of $10 \mathrm{~min}$. The supernatant was decanted carefully; the pellet was washed thrice with $75 \%$ ethanol, centrifuged at $12000 \mathrm{rcf}$ for $15 \mathrm{~min}$. The pellet was air dried and re-suspended in $20 \mu \mathrm{l}$ of RNase free water and stored in $-80^{\circ} \mathrm{C}$ until use. RT-PCR was carried out using PCR master cycler gradient (Eppendorf, Germany) and semi-quantified using Bio1D software in gel documentation (Vilber Loumart, France). The primer sequence of BAX, BCL-2, CYP-450, caspase 3, IL-2 and TNF- $\alpha$ were provided in the Table 1.

\section{Statistical Analysis}

All the grouped data were significantly evaluated with Graph Pad version 5. Mean difference between the 
groups were analysed by one-way analysis of variance (ANOVA) followed Tukey's multiple comparison test as posthoc. $\mathrm{P} \leq 0.05$ is considered to indicate statistical sig-

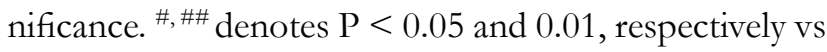
normal control; *, ** denotes $\mathrm{P}<0.05$ and 0.01 , respectively vs D-GLN.

\section{RESULTS}

\section{Curcumin quantification using HPTLC}

HPTLC chromatogram of curcumin and ambrex were quantified (Figure 1). Curcumin content of ambrex was found to be $0.55 \% \mathrm{w} / \mathrm{w}$.

\section{In vivo Study}

\section{Biochemical Observations}

A significant elevation $(p<0.01)$ of ALT, AST, ALP, $\gamma-$ GT and total bilirubin levels were observed in D-GLN induced mice when compared to normal mice. Pre-treatment with Ambrex at two dose levels of 250 $\mathrm{mg} / \mathrm{kg}$ b.wt and $500 \mathrm{mg} / \mathrm{kg}$ b.wt have significantly ( $\mathrm{p}<$ 0.01) decreased the levels of the above indices. Results also clearly revealed significant decrease in the levels of CAT (p < 0.01), SOD ( $p<0.05)$, GSH $(\mathrm{p}<0.01)$ and increase in the levels of TBARS $(p<0.01)$ in liver of D-GLN mice in comparison to normal mice. Ambrex treatment at high dose significantly increased these alterations in comparison to D-GLN induced mice. The values were found to be comparable with that of standard drug, LIV-52 (100 mg/kg b.wt p.o.). (Figure 2-10)

\section{Histopathology}

Histological profile of normal control group revealed normal histology of liver with central vein, hepatocytes and portal triads. D-GLN induced group revealed marked degree of centrilobular necrosis along with polymorphonuclear cells infiltration, severe vacuolations in the hepatocytes and sinusoidal congestion. Pretreatment with LIV-52 reduced galactosamine induced microscopic changes and showed marked beneficial effects in the liver architecture. Ambrex treatment at low dose showed moderate degree of necrosis, mild degree of vacuolations in the hepatocytes with minimal sinusoidal congestion. Ambrex administration at high dose revealed regeneration of hepatocytes to normal architecture, absence of sinusoidal congestion and vacuolations in the hepatocytes. On the basis of above observation, it is concluded that pre-treatment with Ambrex at high dose $(500 \mathrm{mg} / \mathrm{kg}$ b.wt. p.o) have
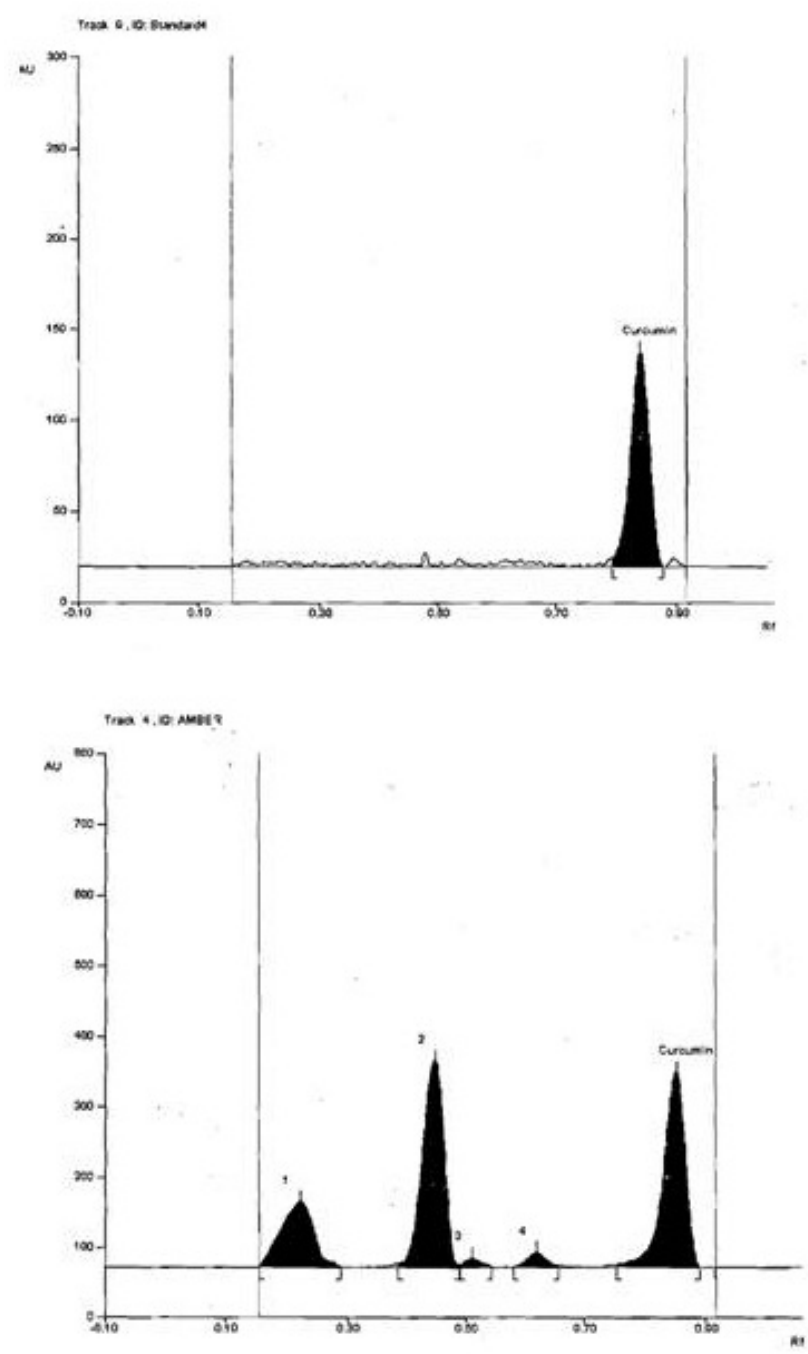

Figure 1: HPTLC chromatogram of curcumin and ambrex.

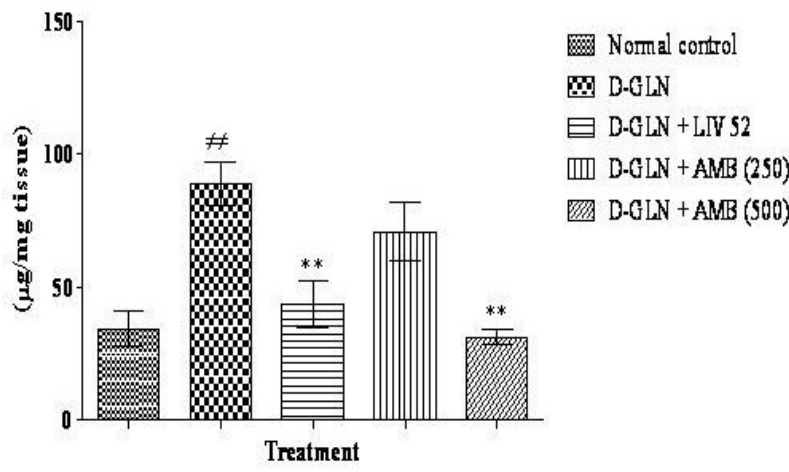

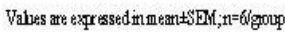

Figure 2: Effect on Ambrex on hepatic lipid peroxidation content in D-galactosamine intoxicated mice. Values are expressed in mean $\pm S E M$; $n=6 /$ group ; Mean difference between the groups were analysed by one way ANOVA followed by Tukey's multiple comparsion test as posthoc; \#\# denotes $\mathrm{P}<0.01$ vs normal control; ** denotes $\mathrm{P}<0.05$ vs D-galactosamine group. 


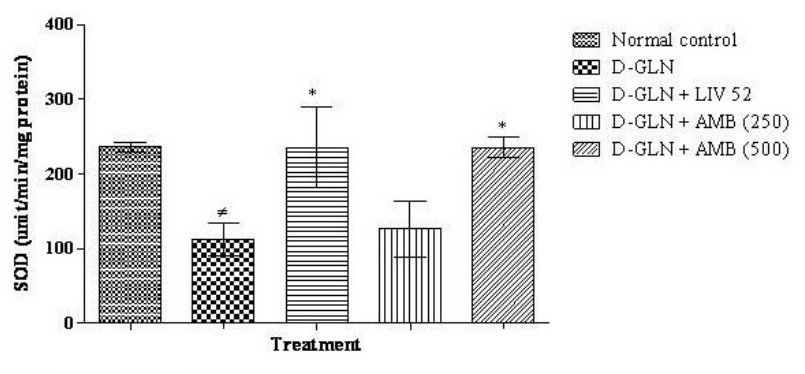

Vahes are expressed in meant $\$$ EM, $n=6$;group

Figure 3: Effect on Ambrex on hepatic superoxide dismutase activity in D-galactosamine intoxicated mice. Values are expressed in mean $\pm S E M ; n=6 / g r o u p ;$ mean difference between the groups were analysed by one way ANOVA followed by Tukey's multiple comparsion test as posthoc; \#\# denotes $\mathrm{P}<0.01$ vs normal control; **denotes $\mathrm{P}<0.05$ vs D-galactosamine group.

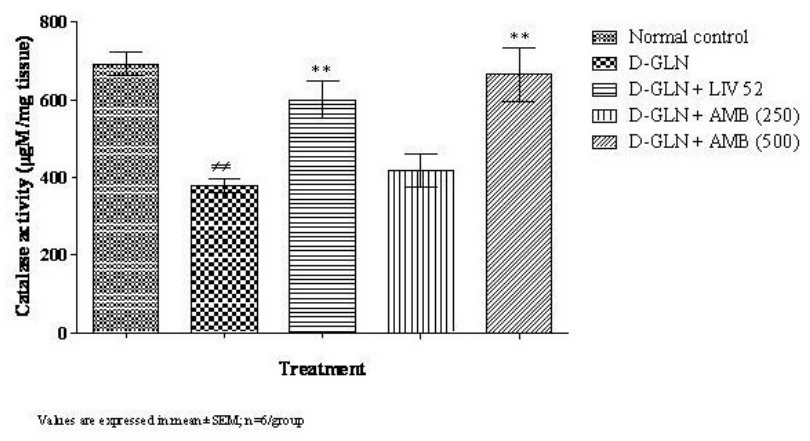

Figure 5: Effect on Ambrex on hepatic catalase activity in $D$-galactosamine intoxicated mice: Values are expressed in mean $\pm S E M$; $n=6 / g r o u p ;$ mean difference between the groups were analysed by one way ANOVA followed by Tukey's multiple comparsion test as posthoc; \#\# denotes $\mathrm{P}<0.01$ vs normal control; **denotes $\mathrm{P}<0.05$ vs $\mathrm{D}$-galactosamine group.

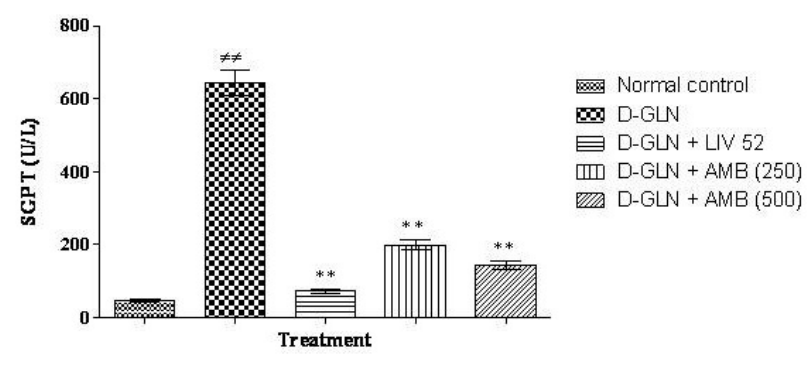

Vahes ane expresed in meant $S E M ; n=6$ group

Figure 7: Effect on Ambrex on SGPT level in D-galactosamine intoxicated miceValues are expressed in mean $\pm S E M$; $n=6 / g r o u p ;$ mean difference between the groups were analysed by one way ANOVAfollowed by Tukey's multiple comparsion test as posthoc; \#\# denotes $\mathrm{P}<0.01$ vs normal control; **denotes $\mathrm{P}<0.05$ vs $\mathrm{D}$-galactosamine group.

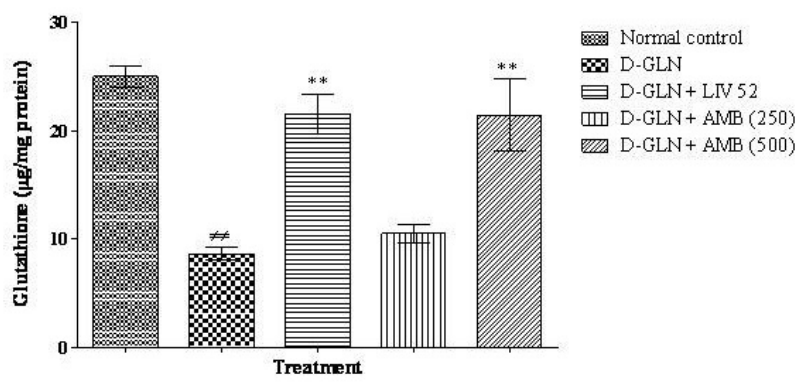

Vahes are expressed inme $m \pm S B M ; n=6 / g r o w$

Figure 4: Effect on Ambrex on hepatic glutathione content in D-galactosamine intoxicated mice. Values are expressed in mean $\pm S E M$; $n=6 / g r o u p ;$ mean difference between the groups were analysed by one way ANOVA followed by Tukey's multiple comparsion test as posthoc; \#\# denotes $\mathrm{P}<0.01$ vs normal control; **denotes $\mathrm{P}<0.05$ vs $\mathrm{D}$-galactosamine group.

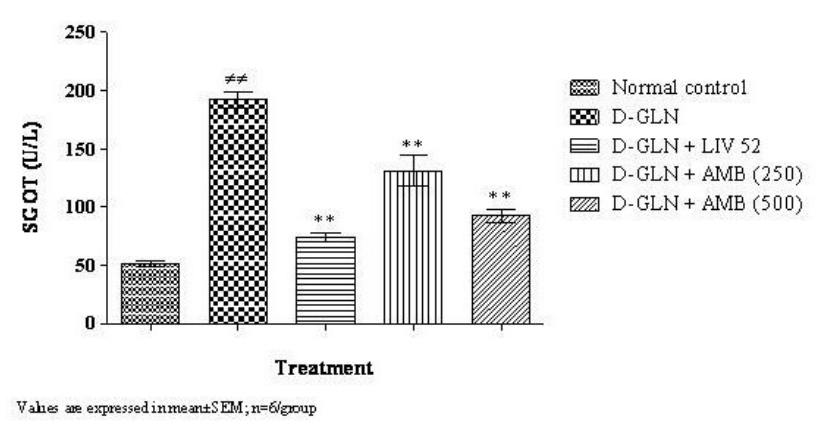

Figure 6: Effect on Ambrex on SGOT level in D-galactosamine intoxicated mice: Values are expressed in mean $\pm S E M$; $n=6 / g r o u p ;$ mean difference between the groups were analysed by one way ANOVA followed by Turkey'smultiple comparsion test as posthoc; \#\# denotes $\mathrm{P}<0.01$ vs normal control; **denotes $\mathrm{P}<0.05$ vs $\mathrm{D}$-galactosamine group.

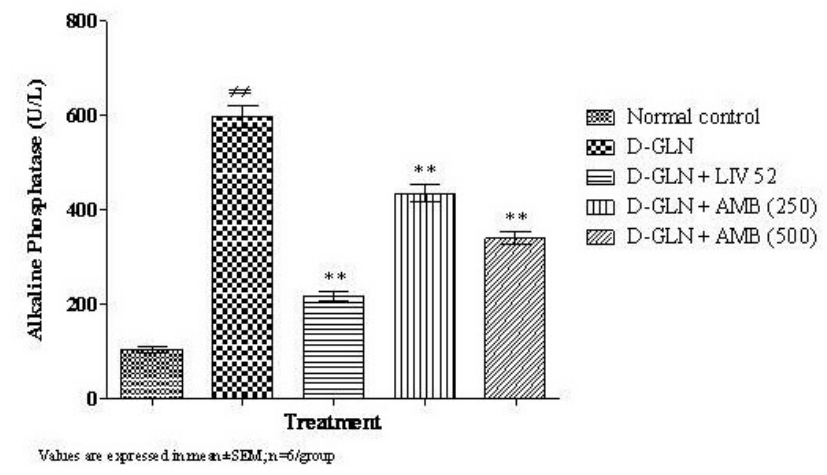

Figure 8: Effect on Ambrex on ALP level in D-galactosamine intoxicated mice: Values are expressed in mean $\pm S E M$; $n=6$ / group; mean difference between the groups were analysed by one way ANOVA followed by Tukey's multiple comparsion test as posthoc; \#\# denotes $\mathrm{P}<0.01$ vs normal control; ${ }^{* *}$ denotes $\mathrm{P}<0.05$ vs $\mathrm{D}$-galactosamine group. 
hepatoprotective activity against D-GLN induced hepatotoxicity. (Figure 11)

\section{In vitro Study}

\section{Cytotoxicity assay}

Cytotoxicity was assessed for D-GLN and Ambrex at concentration range of $1-1000 \mu \mathrm{M} / \mathrm{ml}$ and $1 \mathrm{X} 10^{-}$ ${ }^{3}-1 \mathrm{X} 10^{6} \mathrm{ng} / \mathrm{ml}$, respectively following $24 \mathrm{~h}$ incubation. It was observed from the results that D-GLN exhibited cytotoxicity in a concentration dependent manner and its $\mathrm{IC}_{50}$ was found to be $30.83 \mu \mathrm{M}$. Ambrex exhibited an $\mathrm{IC}_{50}$ value of $44.73 \mathrm{ng}$ when exposed in chang liver cells for a period of $24 \mathrm{~h}$. Hence, hepatoprotective effect of ambrex against D-GLN induced toxicity was carried out at three different concentrations of 5, 50 and $500 \mathrm{ng} /$ ml. (Figure 12, 13)

\section{$R T-P C R$ analysis}

D-GLN induced Chang liver cells showed significant ( $p$ $<0.01$ ) increase in CYP-450, BAX, Caspase 3, TNF- $\alpha$ and IL-2 gene expressions and decrease in BCL-2 expression when compared to normal cells. Ambrex exposure at 5, 50 and $500 \mathrm{ng} / \mathrm{ml}$ significantly and dose dependently down-regulated CYP-450 ( $\mathrm{p}<0.01$ ), BAX ( $\mathrm{p}<0.05, \mathrm{p}<0.01$ and $\mathrm{p}<0.001$ respectively), Caspase 3 ( $\mathrm{p}<0.05,0.01$ and 0.01 , respectively), TNF- $\alpha(\mathrm{p}<$ $0.05, \mathrm{p}<0.01$ and $\mathrm{p}<0.001$ respectively) and IL $-2(\mathrm{p}$ $<0.01$ ) gene expressions and up-regulated $\mathrm{BCl} 2$ ( $\mathrm{p}<$ $0.05, \mathrm{p}<0.01$ and $\mathrm{p}<0.001$ respectively) expression in comparison to positive control cells. (Figure 14)

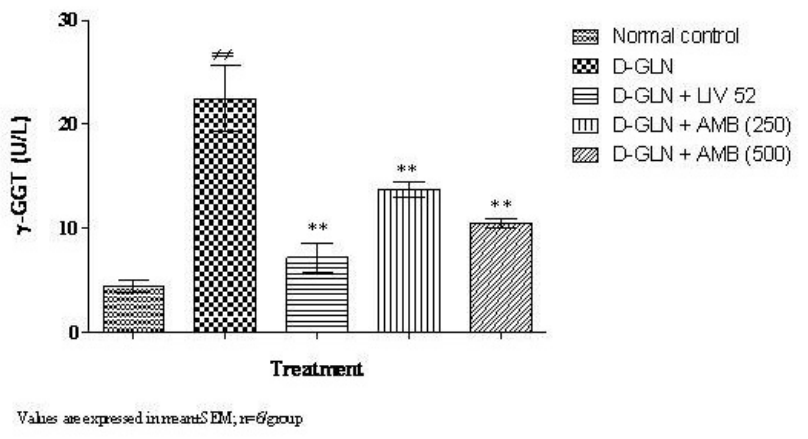

Figure 9: Effect on Ambrex on Y-GGT level in D-galactosamine intoxicated mice: Values are expressed in mean $\pm S E M$; $n=6 /$ group; mean difference between the groups were analysed by one way ANOVA followed by Tukey's multiple comparsion test as posthoc; \#\# denotes $\mathrm{P}<0.01$ vs normal control; **denotes $\mathrm{P}<0.05$ vs $\mathrm{D}$-galactosamine group.

\section{DISCUSSION}

World-wide population from developing countries are being contingent on traditional system of Medicine. Well documented ancient literatures on traditional medicine system publicized the use of plants for various ailments and that many drugs on current use have been derived either directly or indirectly from plant sources. ${ }^{17}$ Use of herbal formulations has gained much importance than single herb due to its better and extended therapeutic potential as well as their easy availability. Perception on polyherbalism has been dated back to 1300 AD in an Ayurvedic literature named Sharangdhar Sambita. ${ }^{18}$ Herbal formulations have been claimed to be more potent as they display synergistic, potentiative, and agonistic/antagonistic actions and the mixture of species in them shows better therapeutic effect than either species on its own. ${ }^{19}$ Hence, the present study investigated the effect of Ambrex, a polyherbal formulation on D-GLN induced hepatic toxicity.

D-GLN induced hepatotoxicity is a widely accepted experimental model as it mimics the morphological and functional alterations caused due to viral hepatitis. ${ }^{20}$ Also, the toxin is more specific to liver because hepatocytes have high levels of galactokinase and galactose-1-uridyltransferase. Reports also showed that galactosamine does not affect other organs. ${ }^{21-22}$ It has been reported that the mechanisms of liver damage induced by DGLN is due to the instability of cellular membranes as a result of lipid peroxidation. ${ }^{23}$ The present study results showed increased MDA levels in D-GLN intoxicated mice, a characteristic parameter of lipid peroxidation ${ }^{24}$

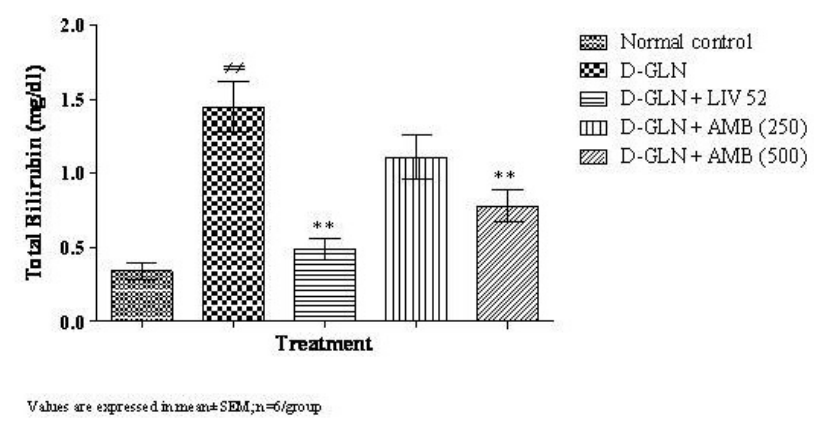

Figure 10: Effect on Ambrex on total bilirubin content in D-galactosamine intoxicated mice: Values are expressed in mean $\pm S E M$; $n=6 / g r o u p ;$ mean difference between the groups were analysed by one way ANOVA followed by Tukey's multiple comparsion test as posthoc; \#\# denotes $\mathrm{P}<0.01$ vs normal control; **denotes $\mathrm{P}<0.05$ vs $\mathrm{D}$-galactosamine group. 


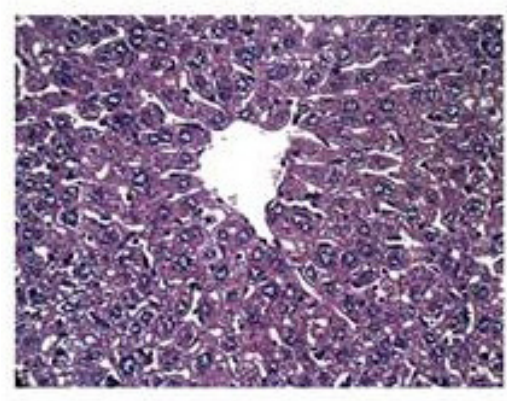

a

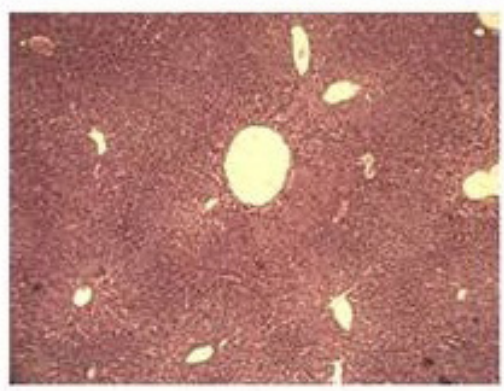

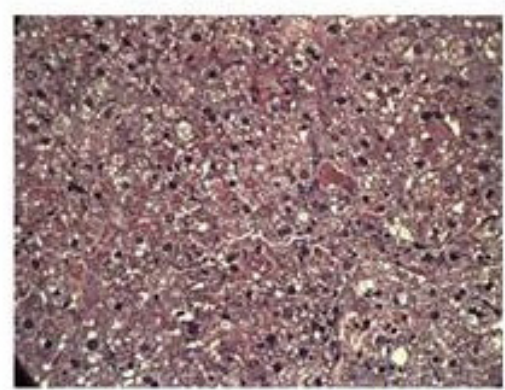

b

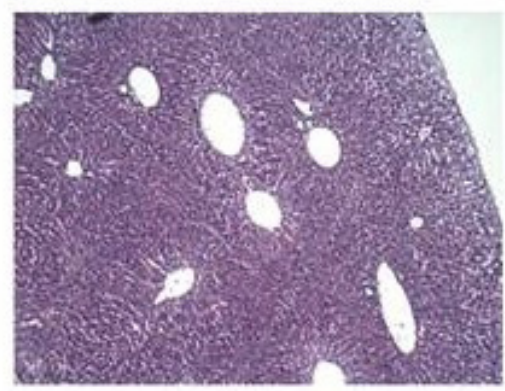

d

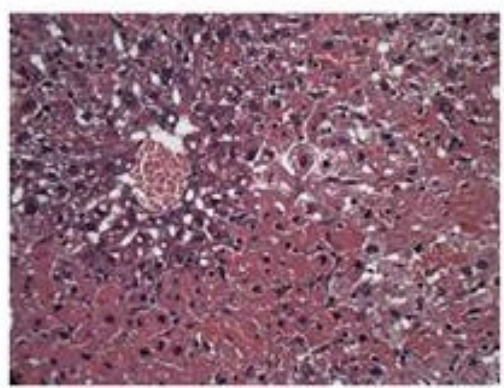

Figure 11. Representative photograph showing the effect of Ambrex on D-galactosamine induced mice liver - H \& E stain. a. Normal control; b. D-Galactosamine $(250 \mathrm{mg} / \mathrm{kg}$ b.wt. i.p.)+Vehicle $+0.5 \% \mathrm{CMC}(10 \mathrm{ml} / \mathrm{kg} \mathrm{b.wt.,p.o)}$ treated group; c. D-Galactosamine (250 mg/kg b.wt. i.p.) + Liv 52 (100 mg/kg b.wt.,p.o) treated group; d. D-Galactosamine (250 mg/kg b.wt. i.p.) + Ambrex(250mg/kg b.wt.,p.o.) treated group; e. D-Galactosamine (250 mg/kg b.wt.i.p.) + Ambrex(500 mg/kg b.wt., p.o.) treated group.

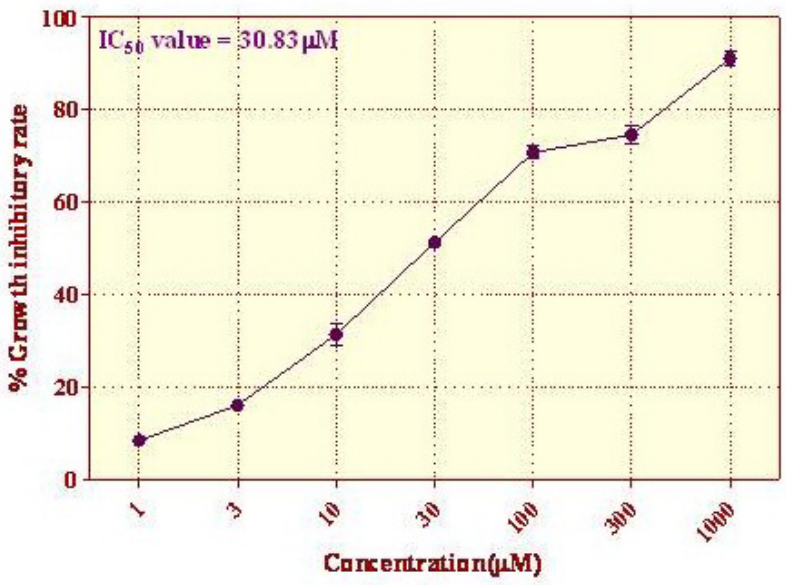

Figure 12: Cytotoxicity of D-galactosamine on chang liver cell line by MTT assay.

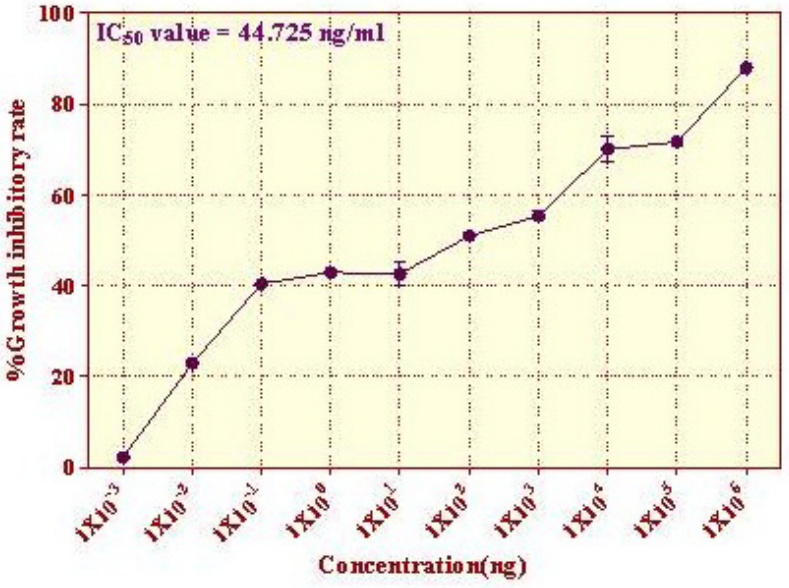

Figure 13: Cytotoxicity of Ambrex on chang liver cell line by MTT assay. 

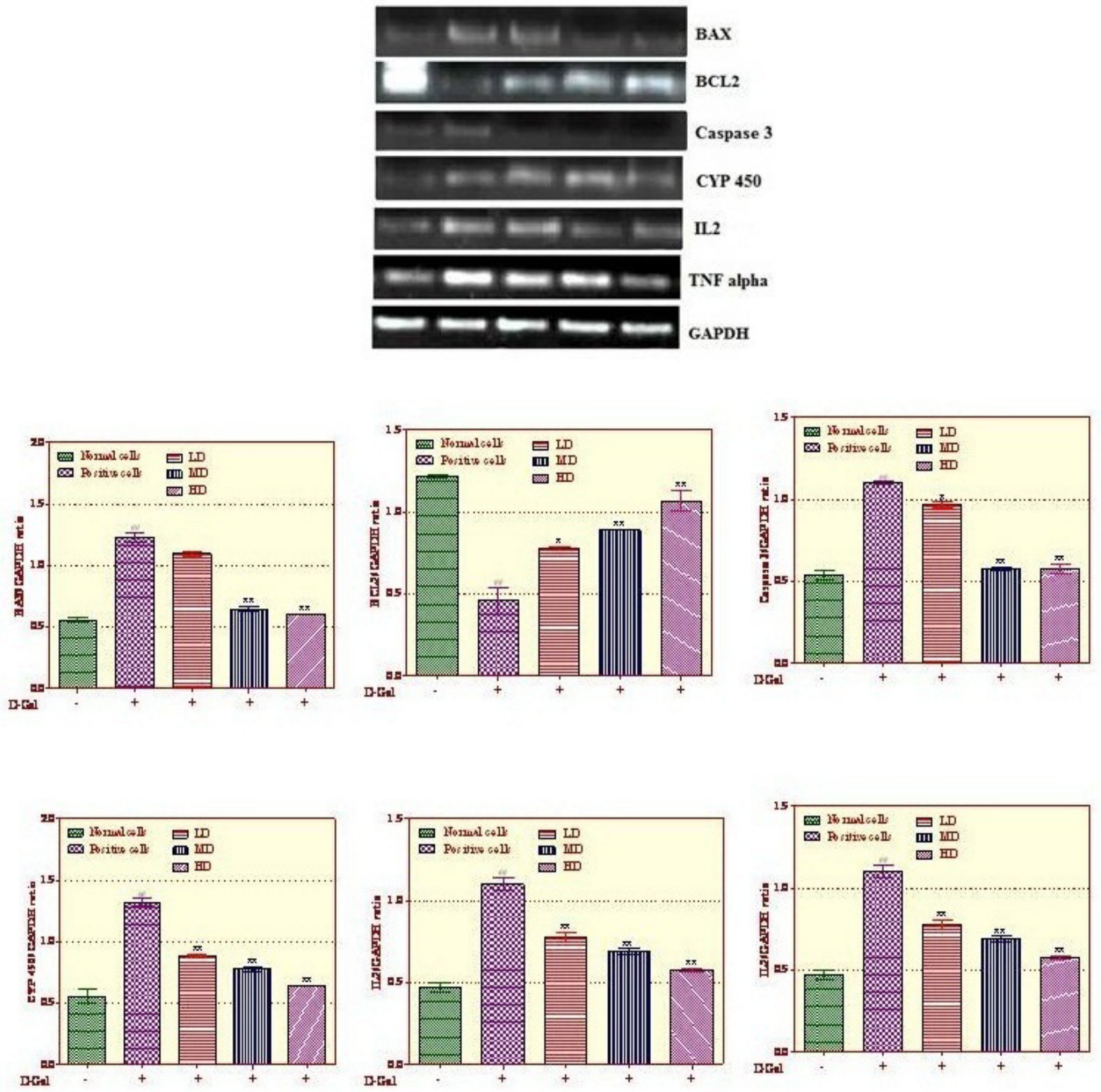

Figure 14: Effect of ambrex on D-galactosamine induced hepatotoxicity in chang liver cell line. (a). Representative bar graphs of mRNA expression.Lane I: Normal control; Lane II: Positive control; Lane III: Low dose; Lane IV: Mid dose; Lane V: High dose. Values were expressed in mean \pm SEM; Statistical analysis was performed using one way anova followed by tukey's multiple comparison tests in Graph pad prism 5.0. \#\# represents $p<0.01$ vs Normal control; ${ }^{*},{ }^{* *}$ represents $p<0.05$ and 0.01 , respectively vs positive control.

\begin{tabular}{|c|c|c|}
\hline \multicolumn{2}{|c|}{ Table 1. Primer sequence for RT-PCR analysis } \\
\hline Primer & Forward Primer & Reverse Primer \\
\hline GAPDH & 5'-CGACAGTCAGCCGCATCTT-3' & 5'-CCAATACGACCAAATCCGTTG-3' \\
\hline BAX & 5'-TTTTGCTTCAGGGTTTCATC-3' & 5'-GACACTCGCTCAGCTTCTTG-3' \\
\hline BCL2 & 5'-ATGTGTGTGGAGAGCGTCAACC-3' & 5'-TGAGCAGAGTCTTCAGAGACAGCC-3' \\
\hline Caspase 3 & 5'-TTTGTTTGTGTGCTTCTGAGCC-3' & 5'-ATTCTGTTGCCACCTTTCGG-3' \\
\hline TNFa & 5'-ATTCTGTTGCCACCTTTCGG-3' & 5'-GAAGGCCTAAGGTCCACTTGTGT-3' \\
\hline IL2 & 5'-GTCACAAACAGTGCACCT AC-3' & 5'-GAAAGTGAATTCTGGGTCCC-3' \\
\hline CYP & 5'-GTGATGCCCTGGCTGCAG-3' & 5'-AATCGAGCTGGATCAAAGTTC-3' \\
\hline
\end{tabular}


whereas mice administered with Ambrex at two doses of $250 \mathrm{mg} / \mathrm{kg}$ b.wt and $500 \mathrm{mg} / \mathrm{kg}$ b.wt significantly attenuated the elevation which was comparable to standard LIV 52 treated group $(\mathrm{p}<0.01)$.

D-GLN causes damage to the functional integrity of the liver cellular membrane leading to leakage of enzymes which ultimately elevates the liver enzyme levels. ${ }^{25}$ Hence substantial increase in the levels of liver enzymes such as AST, ALT, ALP and $\gamma-$ GT are indices of liver damage. It was found from our results that pretreatment with Ambrex was able to protect the damage induced by D-GLN which significantly restored the levels of these enzymes to near normalization. The serum bilirubin level is an index for hepatic function and any deformity found in the levels of the same is been liable to abnormal hepatocellular function. ${ }^{26}$ Elevated levels of total bilirubin in D-GLN intoxicated mice was in agreement with previous reports ${ }^{26-27}$ and Ambrex mediated suppression of the increased bilirubin levels in the treatment groups suggest that the herbal formulation was able to alleviate the hepatobiliary dysfunction.

D-GLN induced hepatotoxicity enhances the production of ROS which is an indirect mechanism of toxicity induction, overwhelming the antioxidant status of the liver and ultimately proceeds to oxidative stress causing liver destruction. ${ }^{28}$ SOD is the first line of defence in the antioxidant system against the oxidative damage mediated by superoxide radicals, catalysing the dismutation of superoxide radical to hydrogen peroxide and oxygen. ${ }^{29}$ It has been reported that Catalase, GSH and GPx also constitute the mutually supportive defense against reactive oxygen species. ${ }^{30-31}$ D-GLN induction has shown to decrease these anti-oxidant levels whereas pre - treatment with Ambrex has significantly increased the anti-oxidant levels compared to that of standard group. Ultra-structural studies also revealed the hepatoprotective efficacy of Ambrex.

The hepatoprotective effect of Ambrex was also evaluated in Chang liver cells. This human liver cell line is considered an appropriate model to study in vitro toxicity in the liver since it retains many of the specialized functions which are characteristics of normal human hepatocytes. ${ }^{32}$ Apoptosis is a crucial pathologic alteration in liver disease, including viral hepatitis, ${ }^{33}$ liver ischemia, ${ }^{34}$ chemical $^{35}$ and drug-induced ${ }^{36}$ liver injury as well as fatty liver disease. ${ }^{37}$ The results of our present study showed that D-GLN induction has led to elevated levels of BAX and Caspase 3 as well as decreased levels of $\mathrm{BCl}-2$. Also increased production of ROS sensitize the hepatocytes to tumour necrosis factor $(\mathrm{TNF}-\alpha)$. Increased levels of CYP-450 and IL-2 were also indicated in our study following exposure of cells to D-
GLN. The present study demonstrated that Ambrex at 5, 50 and $500 \mathrm{ng} / \mathrm{ml}$ down-regulated the pro - apoptotic markers BAX, Caspase 3 and up-regulated the anti - apoptotic marker BCl-2, including CYP-450 and IL-2. Ambrex pre-treatment reversed the changes in the levels of mRNA assessed indicates its anti-apoptotic and hepatoprotective action.

\section{CONCLUSION}

In conclusion, the present study demonstrated that Ambrex has preventive potential as a hepatoprotective agent which was evident from in vivo and in vitro studies. This preventive action of Ambrex might be attributed to the synergistic potential of the herbs present in the formulation.

\section{ACKNOWLEDGEMENT}

None

\section{CONFLICT OF INTEREST}

Authors declare no conflict of interest.

\section{ABBREVIATION USED}

TNF- $\alpha$ : Tumour necrosis factor $\alpha$; IL-2: Interleukin 2; CYP-450: Cytochrome P 450; DNA: Deoxyribonucleic acid; RNA: Ribonucleic acid; RNase: Ribonuclease; PCR: Polymerase Chain reaction; MDA: Malondialdehyde; GPx: Glutathione peroxidase.

\section{REFERENCES}

1. Kmieć Z, Smoleński RT, Zych M, Myśliwski A. The effects of galactosamine on UTP levels in the livers of young, adult and old rats. Actabiochimica Polonica. 2000;47(2):349-53. PMid:11051199.

2. Keppler DO, Pausch J, Decker K. Selective Uridine Triphosphate Deficiency Induced by d-Galactosamine in Liver and Reversed by Pyrimidine Nucleotide Precursors Effect On Ribonucleic Acid Synthesis. Journal of Biological Chemistry. 1974;249(1):211-6. PMid:4809627.

3. Mangeney-Andreani M, Sire $O$, Montagne-Clavel J, Nordmann R, Nordmann J. Inhibitory effect of D-galactosamine administration on fatty acid oxidation in rat hepatocytes. FEBS letters. 1982;145(2):267-70. https://doi. org/10.1016/0014-5793(82)80180-4.

4. Javle P, Yates J, Kynaston HG, Parsons KF, Jenkins SA. Hepatosplanchnic haemodynamics and renal blood flow and function in rats with liver failure. Gut. 1998;43(2):272-9. https://doi.org/10.1136/gut.43.2.272; PMid:10189857 PMCid:PMC1727229.

5. Leist M, Gantner F, Naumann H, Bluethmann H, Vogt K, Brigelius-Flohe R, Nicotera P, Volk HD, Wendel A. Tumor necrosis factor-induced apoptosis during the poisoning of mice with hepatotoxins. Gastroenterology. 1997;112(3):923-34. https://doi.org/10.1053/gast.1997.v112.pm9041255; PMid:9041255.

6. Sheriff SA, Devaki T. Lycopene stabilizes liver function during D-galactosamine/lipopolysaccharide induced hepatitis in rats. Journal of Taibah University for Science. 2013;7(1):8-16. https://doi.org/10.1016/j. jtusci.2013.01.002. 
7. Sheriff SA, Devaki T. Lycopene stabilizes lipoprotein levels during D-galactosamine/lipopolysaccharide induced hepatitis in experimental rats. Asian Pacific journal of tropical biomedicine. 2012;2(12):975-80. https://doi. org/10.1016/S2221-1691(13)60009-X.

8. Devi RS, Narayan S, Mohan KV, Sabitha KE, Devi S. Effect of a polyherbal formulation, Ambrex, on butylated hydroxy toluene (BHT) induced toxicity in rats.Indian J Exp Biol. 2003;41(11):1294-99. PMid:15332500.

9. Jainu M, Devi CS. Effect of Ambrex (an amber based formulation) on gastric mucosal damage: role of antioxidant enzymes and lipid profile. Indian journal of physiology and pharmacology. 2004;48(3):343-7. PMid:15648407.

10. Devi AJ, Ravindran R, Sankar M, Rajkumar J. Effect of ambrex (a herbal formulation) on oxidative stress in hyperlipidemic rats and differentiation of 3T3-L1 preadipocytes. Pharmacognosy magazine. 2014;10(38):165. https:// doi.org/10.4103/0973-1296.131030; PMid:24914283 PMCid:PMC4048564.

11. Gantait A, Barman T, Mukherjee PK. Validated method for estimation of curcumin in turmeric powder. Ind J of Traditional Med. 2011;10(2):247-50.

12. Kakkar P, Das B, Viswanathan PN. A modified spectrophotometric assay of superoxide dismutase. Ind J of Biochem Biophys. 1984;21(2):130-2. PMid:6490072

13. Ohkawa $\mathrm{H}$, Ohishi $\mathrm{N}$, Yagi K. Assay for lipid peroxides in animal tissues by thiobarbituric acid reaction. Analytical biochemistry.1979;95(2):351-8. https:// doi.org/10.1016/0003-2697(79)90738-3.

14. Moron MS, Depierre JW, Mannervik B. Levels of glutathione, glutathione reductase and glutathione S-transferase activities in rat lung and liver. Biochimica et Biophysica Acta (BBA)-General Subjects. 1979;582(1):67-78. https://doi.org/10.1016/0304-4165(79)90289-7.

15. Sinha AK. Calorimetric Assay of Catalase. Anal Biochem. 1972;47(2): 38994. https://doi.org/10.1016/0003-2697(72)90132-7.

16. Xu Z, Cawthon D, McCastlain KA, Slikker W, Ali SF. Selective alterations of gene expression in mice induced by MPTP. Synapse. 2005;55(1):45-51. https://doi.org/10.1002/syn.20089; PMid:15499605.

17. Petchi RR, Vijaya C, Parasuraman S. Antidiabetic activity of polyherbal formulation in streptozotocin-nicotinamide induced diabetic Wistar rats. Journal of traditional and complementary medicine. 2014;4(2):108-17. https:// doi.org/10.4103/2225-4110.126174; PMid:24860734 PMCid:PMC4003700.

18. Srivastava S, Lal VK, Pant KK. Polyherbal formulations based on Indian medicinal plants as antidiabetic phytotherapeutics. Phytopharmacology. 2012;2(1):1-5.

19. Sujatha S, Shalin JJ. Complementary therapeutic potential: A focus on polyherbal products for hyperglycemia. Asian J Sci Res. 2012;5(3):1-13. https://doi.org/10.3923/ajsr.2012.1.13.

20. Keppler D, Decker K. Studies on the Mechanism of Galactosamine Hepatitis: Accumulation of Galactosamine-1-Phosphate and its Inhibition of UDP-Glucose Pyrophosphorylase. European Journal of Biochemistry. 1969;10(2):219-25. https://doi.org/10.1111/j.1432-1033.1969.tb00677.x; PMid:5823097.

21. Maley F, Tarentino AL, McGarrahan JF, DelGiacco R. The metabolism of D-galactosamine and $\mathrm{N}$-acetyl-D-galactosamine in rat liver. Biochemical Journal. 1968;107(5):637-44. https://doi.org/10.1042/bj1070637; PMid:16742584 PMCid:PMC1198715.

22. Keppler DO, Rudigier JF, Bischoff E, Deckker KF. The Trapping of Uridine Phosphates by d-Galactosamine, d-Glucosamine, and 2-Deoxy-dgalactose. European Journal of Biochemistry. 1970;17(2):246-53. https://doi. org/10.1111/j.1432-1033.1970.tb01160.x; PMid:5500393.

23. Yoshikawa T, Yokoe N, Takemura S, Kato H, Hotta T, Matsumura N, Ikezaki M, Hosokawa K, Kondo M. Lipid peroxidation and lysosomal enzymes in D-galactosamine hepatitis and its protection by vitamin E. Journal of Gastroenterology. 1979;14(1):31-9.

24. Sakaguchi S, Yokota K. Role of $\mathrm{Ca} 2+$ on Endotoxin-Sensitivity by Galactosamine Challenge: Lipid Peroxide Formation and Hepatotoxicity in Zymosan-Primed Mice. Basic \& Clinical Pharmacology \& Toxicology. 1995;77(2):81-6. https://doi.org/10.1111/j.1600-0773.1995.tb00993.x.

25. Mitra SK, Seshadri SJ, Venkataranganna MV, Gopumadhavan S, Udupa UV, Sarma DN. Effect of HD-03-a herbal formulation in galactosamineinduced hepatopathy in rats. Indian Journal of physiology and pharmacology. 2000;44(1):82-6. PMid:10919100.

26. Maezono K, Mawatari K, Kajiwara K, Shinkai A, Maki T. Effect of alanine on D-galactosamine-induced acute liver failure in rats. Hepatology. 1996;24(5):1211-6. https://doi.org/10.1053/jhep.1996.v24.pm0008903400; https://doi.org/10.1002/hep.510240538; PMid:8903400.

27. Shivashangari KS, Ravikumar V, Vinodhkumar R, Sheriff SA, Devaki T. Hepatoprotective potential of lycopene on D-galactosamine/ lipopolysaccharide induced hepatitis in rats. Pharmocologyonline. 2006;2:151-70.

28. Sun Y. Free radicals, antioxidant enzymes, and carcinogenesis. Free Radical Biology and Medicine. 1990;8(6):583-99. https://doi.org/10.1016/08915849(90)90156-D.

29. Halliwell B, Gutteridge JMC. Free Radicals in Biology and Medicine. 2nd ed. Clarendon Press, Oxford, UK. 1989; 543.

30. Seifried HE, Anderson DE, Fisher EI, Milner JA. A review of the interaction among dietary antioxidants and reactive oxygen species. The Journal of nutritional biochemistry. 2007;18(9):567-79. https://doi.org/10.1016/j. jnutbio.2006.10.007; PMid:17360173.

31. Valko M, Leibfritz D, Moncol J, Cronin MT, Mazur M, Telser J. Free radicals and antioxidants in normal physiological functions and human disease. The international journal of biochemistry \& cell biology. 2007;39(1):44-84. https:// doi.org/10.1016/j.biocel.2006.07.001; PMid:16978905.

32. Chang RS. Continuous Subcultivation of Epithelial-like Cells from Normal Human Tissues. *. Proceedings of the Society for Experimental Biology and Medicine. 1954;87(2):440-3.https://doi.org/10.3181/00379727-87-21406; PMid:13237268.

33. Wang $\mathrm{WH}$, Hullinger $\mathrm{RL}$, Andrisani $\mathrm{OM}$. Hepatitis $B$ virus $X$ protein via the p38MAPK pathway induces E2F1 release and ATR kinase activation mediating p53 apoptosis. Journal of Biological Chemistry. 2008;283(37):25455-67. https://doi.org/10.1074/jbc.M801934200; PMid:18606816 PMCid:PMC2533071

34. Cursio R, Colosetti P, Auberger P, Gugenheim J. Liver apoptosis following normothermic ischemia-reperfusion: in vivo evaluation of caspase activity by FLIVO assay in rats. Transplant Proc. 2008;40(6):2038-41. https:// doi.org/10.1016/j.transproceed.2008.05.037; https://doi.org/10.1016/j. transproceed.2008.05.039. PMid:18675124.

35. Zhao D, Liu G. Protective effect of bicyclol on concanavalin A-induced liver nuclear DNA injury in mice. Zhonghua yi xue za zhi. 2001;81(14):844-8.

36. Li Y, Dai GW, Liu GT. Effect of bicyclol on acetaminophen-induced hepatotoxicity: energetic metabolism and mitochondrial injury in acetaminophen-intoxicated mice. Yao xue xue bao= Acta pharmaceutica Sinica. 2001 Oct;36(10):723-6.

37. Tessari P, Coracina A, Cosma A, Tiengo A. Hepatic lipid metabolism and non-alcoholic fatty liver disease. Nutrition, Metabolism and Cardiovascular Diseases. 2009;19(4):291-302. https://doi.org/10.1016/j. numecd.2008.12.015; PMid:19359149. 


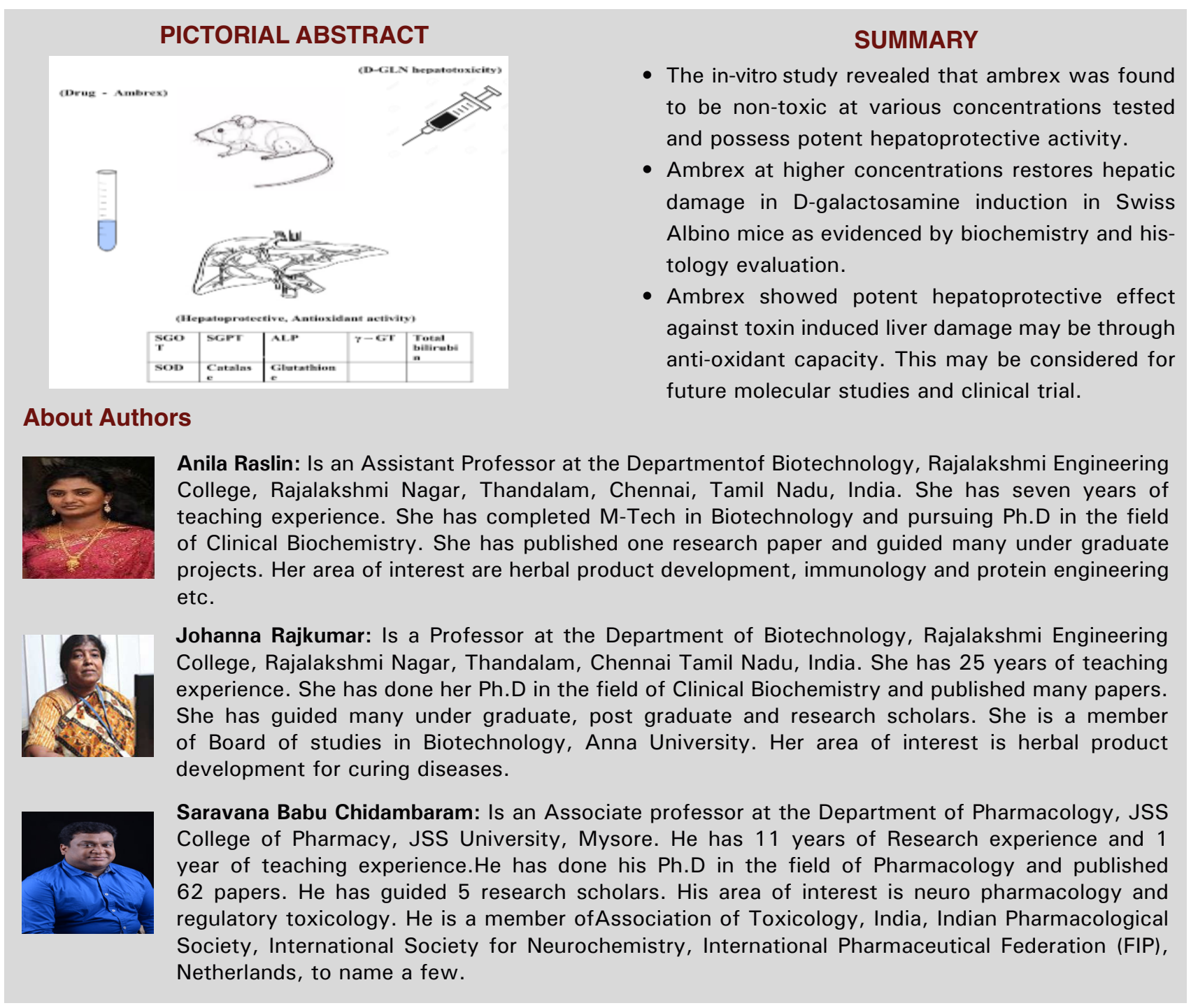

Cite this article: Raslin A, Sathiya S, Babu CS, Rajkumar J. Attenuation of Oxidative Stress and Hepatotoxicity Induced By D-Galactosamine by a Polyherbal Formulation Ambrex-in vivo and in vitro Studies. Indian Journal of Pharmaceutical Education and Research. 2017;51(4):729-39 